NASA Technical Memorandum 105844

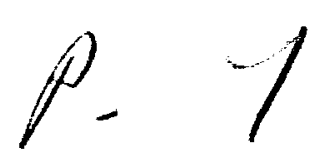

\title{
Load Converter Interactions With the Secondary System in the Space Station Freedom Power Management and Distribution DC Test Bed
}

Ramon C. Lebron

Lewis Research Center

Cleveland, Ohio

August 1992

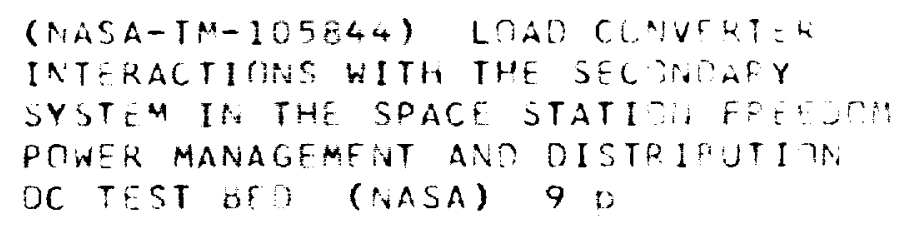





\title{
LOAD CONVERTER INTERACTIONS WITH THE SECONDARY SYSTEM IN THE SPACE STATION FREEDOM POWER MANAGEMENT AND DISTRIBUTION DC TEST BED
}

\author{
Ramon C. Lebron \\ National Aeronautics and Space Administration \\ Lewis Research Center \\ Cleveland, Ohio 44135
}

\begin{abstract}
The NASA Lewis Research Center in Cleveland, Ohio, is responsible for the design, development, and assembly of the Space Station Freedom (SSF) Electrical Power System (EPS). In order to Identify and understand system level issues during the SSF Program design and development phases, a system Power Management and Distribution (PMAD) DC test bed was assembled. Some of the objectives of this test bed facility are the evaluation of, system efficlency, power quality, system stability, and system protection and reconfiguration schemes. In order to provide a realistic operating scenario, dc Load Converter Units are used in the PMAD dc test bed to characterize the user interface with the power system. These units are dc to dc converters that provide the final system regulation before power is delivered to the load. This final regulation is required on the actual space station because the majority of user loads will require voltage levels different from the secondary bus voltage. This paper describes the testing of load converters in an end to end system environment (from solar array to loads) where their interactions and compatibility with other system components are considered. Some of the system effects of interest that are presented include load converters transient behavior interactions with protective current limiting switchgear, load converters ripple effects, and the effects of load converter constant power behavior with protective features such as foldback.
\end{abstract}

\section{INTRODUCTION}

The PMAD dc test bed power system consists of a $160 \mathrm{~V}$ dc primary distribution system which is converted to a $120 \mathrm{~V}$ dc for secondary distribution to the user loads [1]. In this system, regulation is provided at three different locations within the distribution system. This feature constitutes an essential difference between the SSF EPS and existing aircraft power systems because, typically, aircratt systems involve only a single series regulating element. The SSF EPS primary distribution regulation is provided at the sources (Sequential Shunt Unit and Battery Charge/Discharge Unit) to convert and regulate solar array or battery voltage to $160 \mathrm{~V} \mathrm{dc}$ [2]. The test bed secondary system utilizes dc to dc converters which provide power to secondary and tertiary power distribution units. The $D C$ to $D C$ Converter Unit (DDCU) provides regulation by converting the primary voltage to $120 \mathrm{~V}$ dc for secondary distribution. Finally, dc load converter units provide the last stage of regulation by converting the secondary voltage to a voltage suitable for the user applications.

Load converters provide unique features that are necessary to effectively test the user interface with the power system. First of all, they are switching regulating units that will affect the system in terms of control loop interactions. Also, load converters contain input and output filtering which will have an effect over the system transient performance and power quality. In addition, they provide protective features, such as foldback and output short circuit protection, that should be properly coordinated with the system protection switchgear to ensure proper operation of the system. Furthermore, electrical isolation between the system and the user load is achieved by means of the transformer in the load converter. Finally, load converters exhibit a constant power load behavior, or negative incremental inpul impedance, which is a very important concern to assess system stability [3].

The PMAD dc test bed channel A secondary system (Figure 2) consists of two $6.25 \mathrm{~kW}$ TRW DDCU's. Each unit is connected to a secondary bus, and the two secondary buses are cross-tied to operate the DDCUs in parallel output configuration. Secondary and tertiary distribution is realized through 65A, 12A, and 3.5A Westinghouse Remote Power Controllers (RPC's). All load is applied to the tertiary buses through load converters, in a mix of $1 \mathrm{~kW}$ units and smaller, high frequency, dc to dc power supplies. Output loads for these converters are current mode 
electronic loads in the case of $1 \mathrm{~kW}$ units and power resistors in the case of smaller units.

Presently, four $1 \mathrm{~kW}$ bulk load converter topologies are used in the test bed system: Westinghouse Swltching Full Bridge (3 units), TRW Series Resonant (1 unit), TRW Series Inductor (1 unit), and TRW Zero Voltage Switching (6 units). The first three topologies are described in [4],[5],[6]. In addition, smaller, off-the-shelf commerclal dc to dc power supplies from Vicor and Abbott have been Integrated into the system in order to Increase the fidelity of the system loads representation.

\section{LOAD CONVERTEAS DESCAIPTION}

\section{Zero Voltage Switching Topology}

The Zero Voltage Swltching (ZVS) topology power stage configuration is shown on Figure 1. It consists of four power MOSFETS switches, with antiparallel diodes, in a full bridge configuration. The unit switching trequency is $100 \mathrm{kHz}$. Q1 and Q4 $(50 \%$ duty cycle) will conduct current through the transformer in one direction while Q2 and Q3 $(50 \%)$ will conduct in the opposite direction, resulting in a Iransformer current that will approach a square wave. The switching scheme is such that, instead of turning on the diagonally opposite swltches in the bridge simultaneously, a phase shift is introduced between the switches in the left leg and those in the right leg. That is, if Q1 and Q4 are conducting, Q2 and Q3 will not be turned on at the same time, a phase shift will separate the tum on of Q2 and Q3. This phase shitt allows the transformer leakage inductance current to discharge the off MOSFET internal (drain-source) capacitance. This forces the antiparaliel diode to conduct prior to the MOSFET turn on, allowing it to tum on at virtually zero voltage. The phase shift determines the operating duty cycle of the converter and provides output voltage regulation. Rated output voltage is $28 \mathrm{~V}$ dc. Measured efficiency varies between $85 \%$ and $91 \%$ for different load conditions.

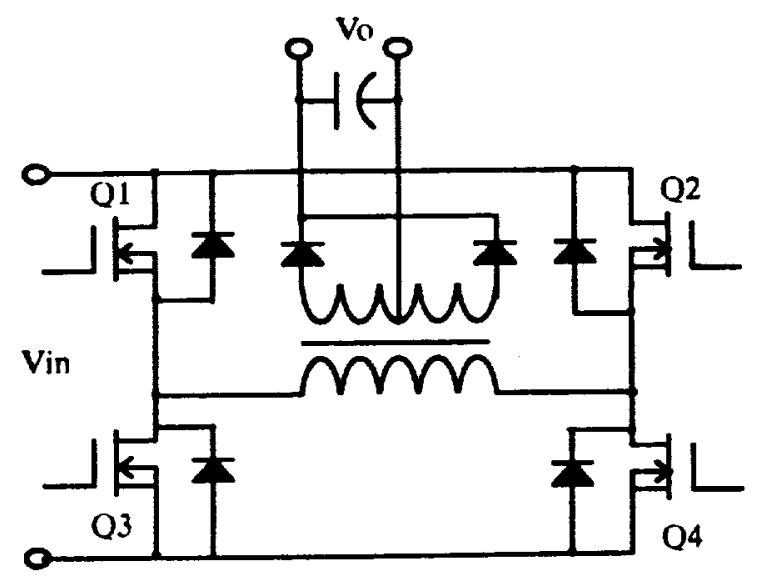

Floure 1. Zero Voltage Switching Topology Power Stage
The unit's operating features include output current limit protection, and input over-voltage trip capability. Its control commands are ON/OFF, output voltage setpoint, and output current limit setpoint. These commands can be applied either manually or through a Data Interface Unit (DIU) for operation with a controller and a Mil. Std. 15538 data bus. The unit, when operated with the DIU, allows monitoring of the input voltage and current, output voltage and current, input/output power, current limit setpoint, and status.

\section{VICOR and ABBOTT de to dc Power Supplles}

Vicor dc to dc power supplies used in the test bed system are rated for $50 \mathrm{~W}, 100 \mathrm{~W}, 150 \mathrm{~W}$, and $200 \mathrm{~W}$ with output voltages from $5 \mathrm{~V} \mathrm{dc}$ up to $48 \mathrm{~V} \mathrm{dc}$. These units are single swltch, Zero Current Switching converters that operate at variable switching frequency from $30 \mathrm{kHz}$, at no load, up to $1 \mathrm{MHz}$ at full load. Their nominal input voltage is $150 \mathrm{~V} \mathrm{dc}$, but they can be used with input voltages from $100 \mathrm{~V}$ dc up to $200 \mathrm{~V} \mathrm{dc}$. Measured efficiency varies from $80 \%$ up to $85 \%$ for the different units.

Abbott dc to dc power supplies are $20 \mathrm{~W}$ and $50 \mathrm{~W}$ units with output voltages from $5 \mathrm{~V}$ dc up to $24 \mathrm{~V} \mathrm{dc}$. They are single switch, current mode controlled, forward switching converters operating at a frequency of $200 \mathrm{kHz}$. Input voltage range for these units is $90 \mathrm{~V}$ dc up to $160 \mathrm{~V} \mathrm{dc}$. Measured efficiency varies from $75 \%$ up to $80 \%$ for the different units.

These devices have been integrated into the PMAD test bed system by paralleling the inputs of a group of power supplies with different output voltages and ratings (approximately $300 \mathrm{~W}$ per group). Each group is then fed by a separate 3.5A RPC. In the present configuration of the secondary system, four 3.5A RPC's are feeding dc to dc power supplies (Figure 2).

\section{SECONDARY SYSTEM TEST PERFORMANCE}

The secondary system tests were performed using the configuration of Figure 2. Two DDCU's were paralleled in droop mode, at $100 \%$ power share (sharing power equally). In droop mode, the DDCU's operate independently, with output current proportional to the amount of voltage enror [7]. Input power to the DDCU's was provided by the PMAD test bed Solar Array Simulator through the Loral Sequential Shunt Unit. The test results presented display the system performance of the four load converter topologies but emphasis is given to the salient system interactions. 


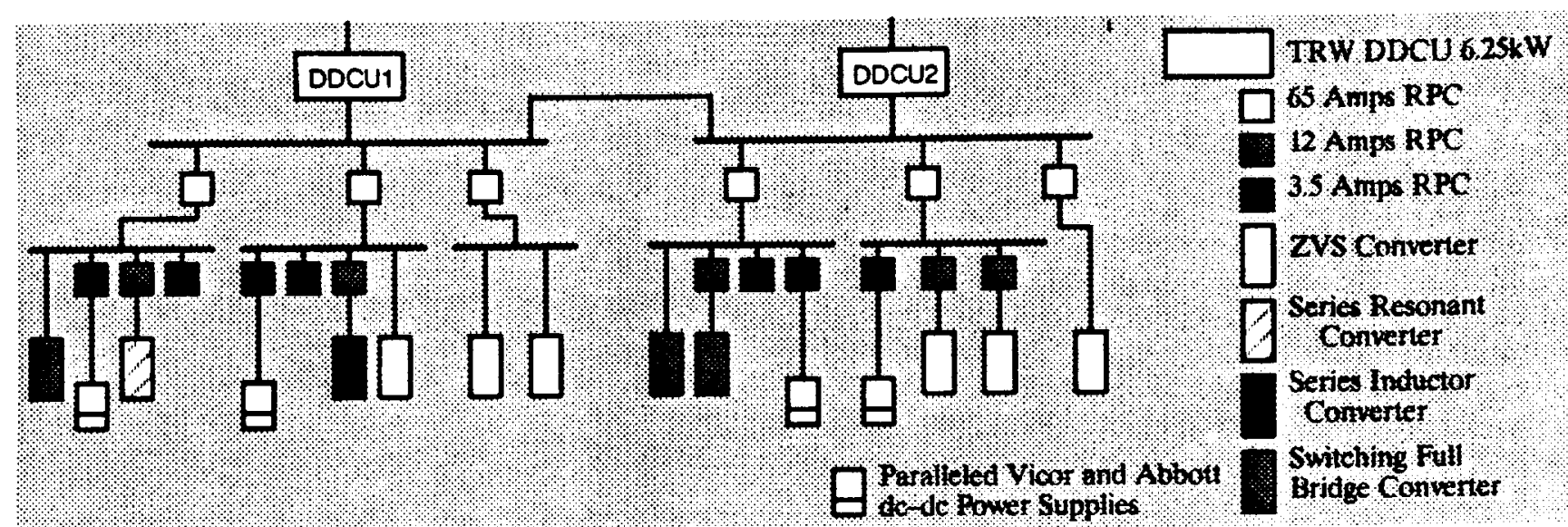

Flgure 2. PMAD DC Teat Bed Secondary Syatem Conflguration

\section{Power Qually Tests}

Power quality tests were performed to evaluate system ripple effects when the secondary system is populated with load converters that operate at different switching frequencies. The total load for these tests was $9.9 \mathrm{~kW}$ at the output of the eleven bulk load converters.

At the output of the DDCU1 the measured current ripple was $450 \mathrm{~mA}$ peak to peak with a frequency of approximately $40 \mathrm{kHz}$ (twice the unit operating frequency) and a low frequency component of approximately $4 \mathrm{kHz}$. Output voltage ripple was approximately $150 \mathrm{mV}$ peak to peak. For DDCU2 the output current and voltage ripple were $337 \mathrm{~mA}$ peak to peak and $240 \mathrm{mV}$ peak to peak respectively.

Ripple measurements were also taken at the input terminals of the $1 \mathrm{~kW}$ load converters connected to the tertiary buses. For the Zero Voltage Switching converter the measured input current ripple was 60 $\mathrm{mA}$ peak to peak and the input voltage ripple was 360 $\mathrm{mV}$ peak to peak with a frequency of approximately $100 \mathrm{kHz}$. The Series Resonant unit's input current ripple was $90 \mathrm{~mA}$ peak to peak with a trequency of approximately $105 \mathrm{kHz}$ and a low frequency component of approximately $4 \mathrm{kHz}$. For the Series Inductor converter, ripple tests showed an input curremt ripple with the similar frequency content as the Series Resonant with an amplitude of $70 \mathrm{~mA}$ peak to peak, and an input voltage ripple of $240 \mathrm{mV}$ peak to peak. In addition, for the Switching Full Bridge converter, the measured input current ripple was 150 mA peak to peak, with a frequency of $10 \mathrm{kHz}$. while its measured input voltage ripple was $360 \mathrm{mV}$ peak to peak.

To evaluate the ripple effects of smaller dc to $d c$ power supplies, the load in each of the eleven $1 \mathrm{~kW}$ converter was reduced to $875 \mathrm{~W}$ and four groups of paralleled power supplies were loaded with approximately $250 \mathrm{~W}$ per group. The total system load was approximately $10.6 \mathrm{~kW}$.

Ripple measurements were taken at the input terminals of two Vicor power supplies, a 200W-24V dc and a $100 \mathrm{~W}-15 \mathrm{~V}$ dc (connected in parallel at their inputs). An interesting interaction between the two units was observed on the voltage and current ripple waveforms. For both waveforms a high frequency component (approximately $570 \mathrm{kHz}$ ) appeared to be amplitude modulated by a $20 \mathrm{kHz}$ component. This effect, which was not present when the units were operated as stand alone units, is due to the fact that both units were not operating at exactly the same switching frequency because the units were not operating at the same percentage of rated load (one was loaded at $90 \%$ of rated load while the other was loaded at $87 \%$ of rated load). As mentioned earlier, the operating frequency of these devices varies according to output load. The observed effect is, thus, the addition of the two unsynchronized waveforms. The amplitude of the input current ripple for this group of power supplies was 225 mA peak to peak while the input voltage ripple was approximately $1.5 \mathrm{~V}$ peak to peak. Such a high input voltage ripple might be unacceptable for actual SSF applications.

The DDCU output current ripple was observed using a spectrum analyzer in order to identify Individual frequency components at the different operating trequencies of the load converters. Spectrum charts were also obtained for the DDCU output current ripple when the secondary system was fully loaded with facility loads, without using any load converter. Comparison of spectrum charts for both loading cases did not reveal significant differences, which implies that the load converters were not contributing significantly to the frequency content of the DDCU output current ripple. This is due to the inherent filtering in the system cabling. The only difference was observed in the frequency range from 
$550 \mathrm{kHz}$ to $1 \mathrm{MHz}$ which corresponds to the operating trequency of the Vicor power supplies.

\section{Start Up Tests}

Load converter start up tests were performed to evaluate the effect of the turn on characteristics of individual devices on the operation of the end to end system. This test was performed by closing the tertiary RPC to apply $120 \mathrm{~V} \mathrm{dC}$ and energize the unit's input filter while the unit was off. The unit was then commanded on into full load (1 kW for bulk converters). After the $1 \mathrm{~kW}$ transient, the total system load for these tests was $10.8 \mathrm{~kW}$ at the output of eleven bulk load converters. This test, like every other transient test in the system, was performed for each of the four load converter topologies.

The Zero Vollage Switching converter turn on resulted in a smooth transition for input current and output voltage, reaching steady state levels (10A, $28 \mathrm{~V}$ dc) in approximately $1.45 \mathrm{msec}$. The bus voltage (input) was not appreciably affected by the transition. The Series Resonant and the Series Inductor Converter showed similar tum on behavior. For both units the output voltage increased to approximately $20 \mathrm{~V}$ and stayed at this level for $1.6 \mathrm{msec}$ then increased to $28 \mathrm{~V} \mathrm{dc}$ in approximately $0.4 \mathrm{msec}$ for a total turn on time of approximately $2 \mathrm{msec}$. The Switching Full Bridge converter start up test produced an initial input current spike of approximately $7.5 \mathrm{~A}$ necessary to charge its 5000 uF output capacitor, then output voltage and input current ramped smoothly to their steady state levels in $3.27 \mathrm{sec}$. This gradual transition was the effect of the unit's sott start capability which allows the ramping of its output voltage according to an adjustable setpoint. Similar to the other units' turn on transitions, no appreciable effect was observed on the unit's input voltage. Thus, start up transition tests showed that, for the four bulk load converter topologies in the test bed system, turn on into full load ( $1 \mathrm{~kW}$ ) does not produce a significant disturbance on the secondary system bus voltage.

\section{Inrush Tests}

Innush tests were performed with the objective of identifying any system interactions that were excited by energizing the load converters input filter. Innush tests consisted of connecting $1 \mathrm{~kW}$ of load to the output of a bulk load converter, turning the unit on, and then closing the tertiary (12 A) RPC to apply $120 \mathrm{~V} \mathrm{dC}$ and energize the unit and its load. For these tests, the total system load, after the $1 \mathrm{~kW}$ transient, was 10.8 $\mathrm{kW}$ at the output of eleven bulk load converters.

The ZVS converter inrush test produced an input current spike of $20 \mathrm{~A}$ intended to charge the unit's input filter. Following this, input current increased to approximately $10 \mathrm{~A}$, decreased to zero and stayed at this level for approximately $43 \mathrm{msec}$, finally increasing to $10 \mathrm{~A}$ for a total inrush time of $105 \mathrm{msec}$. Input voltage showed an initial spike of approximately 80 volts, then increased to $120 \mathrm{~V}$ dc without further disturbances.

For the Series Inductor converter inrush transition (see Figure 3), the unit input current built up to 12A, to charge the unit's input fitter, and stayed at this level until the input voltage increased up to approximately $115 \mathrm{~V} \mathrm{dc}$. At this point current decreased down to zero amps and bullt up to its steady state level (10 A) in approximately $5 \mathrm{msec}$, for a total transition time of $6.22 \mathrm{msec}$. Input voltage spiked up to $40 \mathrm{~V}$ dc before ramping from zero to $120 \mathrm{~V}$ dc. The Serles Resonant converter exhibited similar inrush behavior, but attained its steady state in approximately $52 \mathrm{msec}$. input voltage, after reaching $120 \mathrm{~V}$ dc did not exhibit any noticeable disturbance for the test of both units.
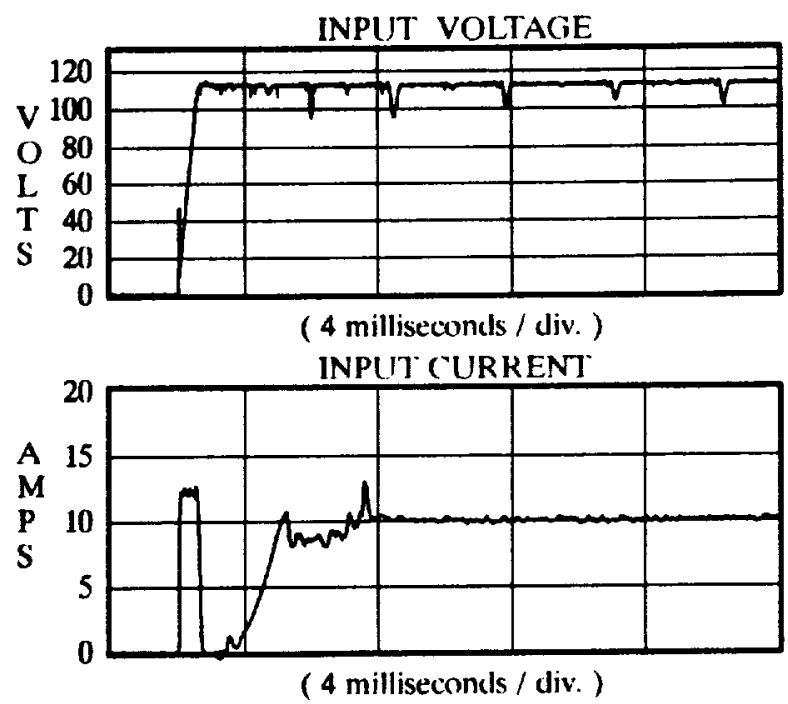

Figure 3. Serles Inductor Converter Inrush Test

Inrush for the Switching Full Bridge converter caused the 12A tertiary RPC feeding the unit to current limit, producing oscillations in the input current (varying from 5A to 20A) and input voltage (varying from $120 \mathrm{~V} \mathrm{dc}$ to $10 \mathrm{~V} \mathrm{dc}$ ). These oscillations were sustained for $95.8 \mathrm{msec}$ before the tertiary RPC tripped on overcurrent. The load on this converter was then reduced to $900 \mathrm{~W}$, and the inrush transient repeated. This time the same current limiting and oscillations were produced but no trip of the tertiary RPC occurred. Input voltage and current reached their steady state value in approximately $95 \mathrm{msec}$. However, for this test, a 12A RPC connected to a different terliary bus tripped on overcurrent. This RPC was feeding a ZVS converter. This indicated that, at this system load level the inrush transition interaction between the Switching Full Bridge converter input filter and its current limiting RPC, produced an overload on the DDCU's output. This overload caused the secondary bus voltage to decrease, inducing an increase in load converter current 
(constant power load), which explains the overcurrent trip of the RPC feeding a load converter in a different tertiary bus. By reducing the total load on the output of the DDCU, the switching full bridge converter was able to energize $900 \mathrm{~W}$ of load without tripping other RPC's in the system. With the original DDCU load condition ( $9.8 \mathrm{~kW}$ before the transient), the maximum load that could be energized by innush of the Switching Full Bridge was $800 \mathrm{~W}$ (see Figure 4). This transition, in spite of the unacceptable oscillations generated due to the current limiting action of the RPC, did not give rise to the tripping of any other secondary system RPC.

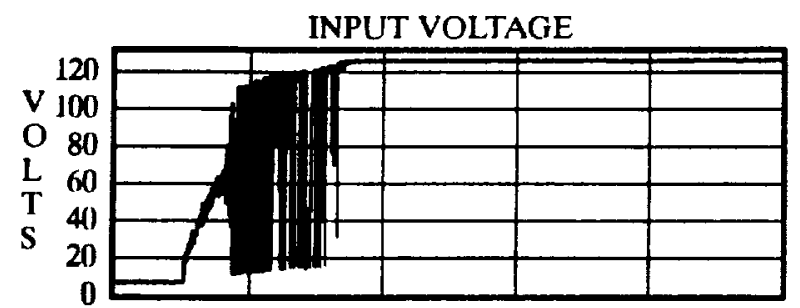

( 40 milliseconds / div. )

INPUT CURRENT

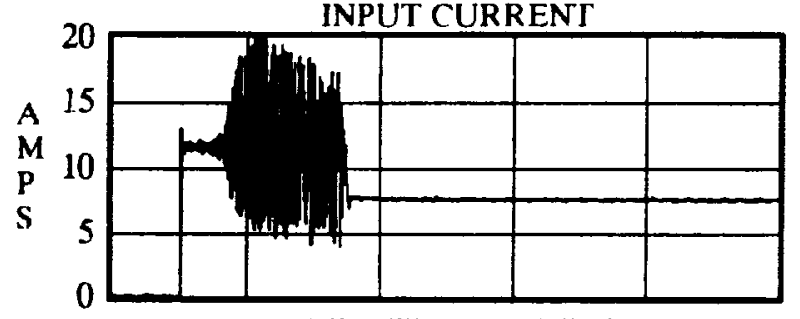

( 40 milliseconds / div.)

Figure 4. Switehing Full Bridge Converter Inrush Teat

These tests demonstrated the need for proper coordination between the secondary system protection switchgear and the inrush characteristics of load converters in the operation of an end to end system with variable load demand. This becomes relevant for loads that do not provide means for on/off control, which have to be energized by closing a tertiary RPC.

\section{Load Step Tests}

Load Step transients tests were performed for each bulk load converter topology on the test bed system. These tests were performed by turning the load converter on into $100 \mathrm{~W}$ of electronic load and then commanding this load to $1 \mathrm{~kW}$ to provide a load step from $10 \%$ to $100 \%$ of rated output load. Total load for the system after the $900 \mathrm{~W}$ transient was 10.5 kW.

The Zero Voltage Switching converter load step test showed an input current, which increased from approximately $1 \mathrm{~A}$ up to $18 \mathrm{~A}$ and then oscillated between $18 \mathrm{~A}$ and $5 \mathrm{~A}$ reaching its steady state level of $10 \mathrm{~A}$ in approximately 816 microseconds. The input voltage exhibited two $40 \mathrm{~V}$ dc voltage dips which correspond to the points at which the input current decreased to 5A. This disturbance, however, did not originate any undesirable interaction with other converter units or tertiary RPC's. That is, the DDCU's output voltage was not appreciably affected by the disturbance.

The Series Inductor and Series Resonant converter load step transients appeared to be identical. For both units, input current increased smoothly to the steady state value of $10 \mathrm{~A}$ in approximately $\mathbf{3 5 0}$ microseconds, with an overshoot of 4 amps.

The Switching Full Bridge converter load step (see Figure 5) produced an input current overshoot that resulted in the tertiary RPC current limiting. This generated some oscillation in the input current for approximately $1.6 \mathrm{msec}$. During this time input voltage dips of approximately $40 \mathrm{~V}$ dc were observed. These voltage dips did not significantly affect other system components. Steady state was reached in 4.1 msec.

INPUT VOLTAGE

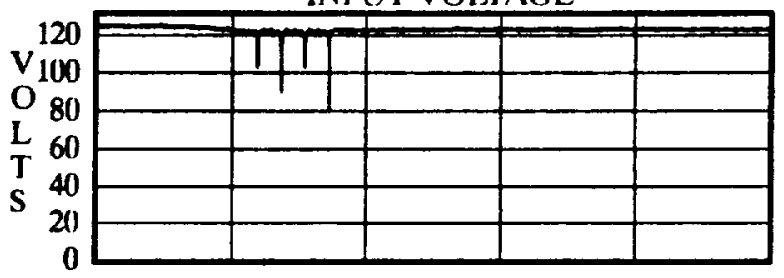

( 1.6 miliseconds / div. )

INPUT CURRENT

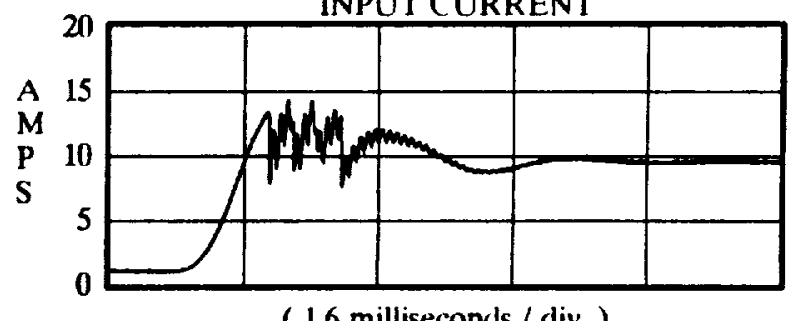

( 1.6 milliseconds / div. )

Flgure 5. Switching Full Brldge Converter Load Step Test

\section{Overload Test}

Load converter overload tests were performed by operating each load converter at full load and then stepping the programmable load bank from $1 \mathrm{~kW}$ to $1.2 \mathrm{~kW}$ to provide a step from $100 \%$ to $120 \%$ of rated load. The total system load prior to the transient was $10.5 \mathrm{~kW}$ at the output of the eleven bulk load converters.

For the ZVS converter (see Figure 6) and the Series Resonant converter the outcome of the transition was basically the same. The units' output current increased to approximately $41 \mathrm{~A}$ while output voltages decreased from $28 \mathrm{~V} d c$ to approximately 20 $\checkmark$ dc. Input current decreased to approximately $8 A$. The transitions were smooth and no notable effects 
were obsenved either in the converters input voltages or in the DDCU's output voltage.

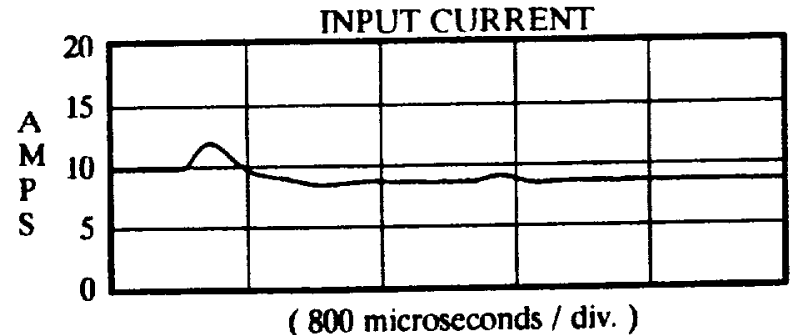

OUTPUT VOLTAGE

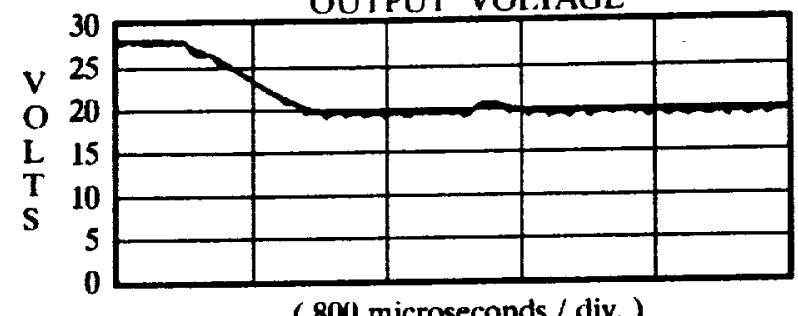

( 800 microseconds / div.)

Figure 6. Zero Voltage Swhching Converter Overload Tost

In contrast, the Switching Full bridge converter was able to withstand the overload with an output voltage reduction from $28.5 \mathrm{~V}$ dc to $27.1 \mathrm{~V}$ dc. The input and output currents increased to $11 \mathrm{~A}$ and 41A, respectively, without affecting the unit input voltage.

On the other hand, the Series Inductor converter overload transient (see figure 7) induced the tertiary RPC feeding it to current limit. This produced oscillation in the input current (20A-0A) for approximately $2.5 \mathrm{msec}$. After this time the RPC continued to current limit without osclllation, finally tripping in approximately $70 \mathrm{msec}$.

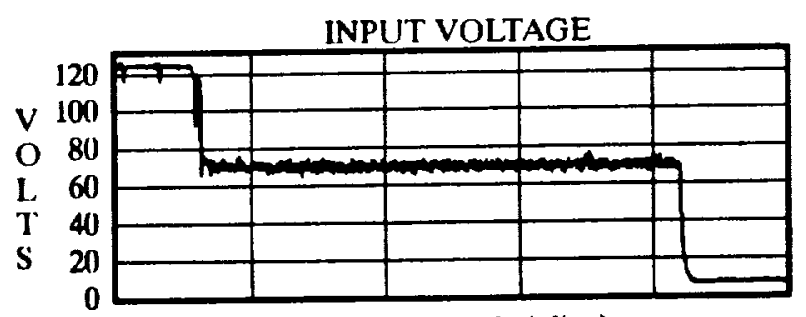

( 20 milliseconds / div. )

INPUT CURRENT

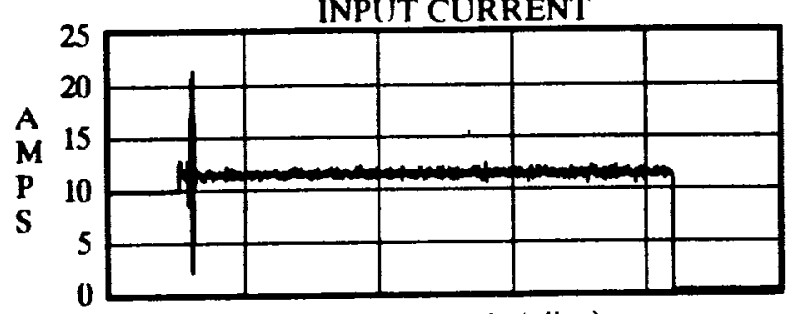

( 20 milliseconds / div. )

Flgure 7. Series Inductor Converter Overlond Test

These tests showed that an overload condition in the output of a load converter will affect the output voltage regulation of the converter, but the unit input voltage will not be affected if the load converter input current remains below the current limit setpoint of the tertiary RPC feeding it.

\section{Short Circult Tests}

Short circult test were performed to evaluate how the system is affected by a hard fault at the output of a load converter. The fault was implemented by closing a knife switch to short the output terminals of a converter operating at full load. For these tests the total system load prior to the fault was $10.5 \mathrm{~kW}$ at the output of the eleven bulk load converter units.

The ZVS converter output short circult produced an output current that splked trom $36 \mathrm{~A}$ of to $120 \mathrm{~A}$ and decreased with underdamped oscillations to approximately $45 \mathrm{~A}$ in $\mathbf{4 1 0}$ microseconds. During this time input current decreased smoothly from 10A to OA and increased back to its steady state value of approximately $1.7 \mathrm{~A}$. No effect could be observed on the unit's input voltage,

The Series Resonant Converter (see Figure 8) output current peaked at $160 \mathrm{~A}$ and reached its steady state level of approximately $41 \mathrm{~A}$ in $1.53 \mathrm{msec}$. Input current decreased to zero in 150 microseconds and then attained its steady state level of $1.7 \mathrm{~A}$. The Series inductor converter exhibited similar behavior but it reached steady state in approximately $2.45 \mathrm{msec}$. For the Switching Full Bridge converter short circuit test, the output current maximum was also 160A. The time needed for the unit to reach steady state was approximately $3.27 \mathrm{msec}$. Steady state levels for the unit's input and output current were 1.7A and 42A, respectively. No significant disturbances were produced on the input voltages of these units.

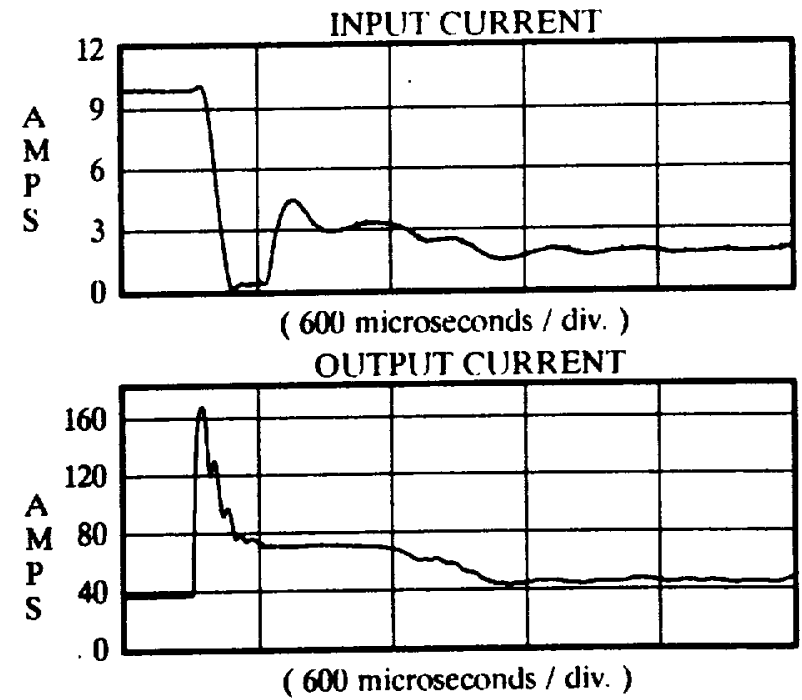

Figure 8. Series Resonant Converter Short Clrcult Test

These tests demonstrated that, under a hard fault on the load side, load conventers will provide protection prior to the tertiary RPC detection of the fault. Output current will be limited to a maximum 
value and input current will drop so that no RPC current limiting occurs and no effect is produced on the secondary bus voltage.

\section{Secondary Bus Voltage Step Down Tests}

Input Voltage step down tests were performed to evaluate the load converters foldback characteristics (transition from constant power mode to constant resistance mode) when fed by a current limiting RPC. These tests were implemented by commanding the DDCU's output voltage setpoint from $130 \mathrm{~V}$ dc down to $95 \mathrm{~V}$ dc in 5 volts intervals. The total system load was $7.5 \mathrm{~kW}$, but the load for each of the load converters under test was $1 \mathrm{~kW}$.

During these tests the Series Pesonant and the Series Inductor converters operated in constant power mode until the DDCU output voltage was commanded down to 105 volts $(103 \mathrm{~V}$ dc at the load converter input terminals). At this point the increase in input current demanded by each unit caused the 12A tertiary RPC feeding it to trip on over current. The Switching Full bridge converter, on the other hand, operated in constant power mode untll the DDCU output voltage was commanded to 101 volts $(97 \mathrm{~V} \mathrm{dc}$ at the load converter terminals) when its tertiary RPC tripped on overcurrent. However, the ZVS converter was able to foldback at an input voltage of $104 \mathrm{~V} \mathrm{dc}$ and a maximum input current of 10.4 A. This transition from constant power to constant resistance mode prevented its RPC from tripping on overcurrent.

The implication of these tests is that if the secondary bus voltage is browned out, because of an overload condition, the load converters will demand more current to try to maintain regulation of their loads. If the secondary protection system is not adequately coordinated, this constant power behavior of the load converters can aggravate the overload condition, causing the secondary voltage to decrease even more. This fact should be caretully considered when integrating an effective secondary protection system.

\section{'SUMMARY}

Four bulk load converters topologies and two commerclal dc to dc power supply implementations have been tested in the secondary system of the PMAD DC test bed. The tests revealed important system effects or interactions which should be carefully considered when integrating an end to end system that utilizes load converters. It was demonstrated that caretul coordination between the secondary system protection switchgear and the transient behavior of load converters is critical to ensure availability of loads and proper operation of the end to end system.

\section{REFERENCES}

[1] R. Beach, L. Trash, B. Bolerjack, "Description of the PMAD DC Test Bed Architecture and Integration Sequence", IECEC-91, August 4-9,1991, Boston, MA.

[2] R. Button and A. Brush, "Development and Testing of a Source Subsystem for the PMAD DC Test Bed", IECEC-91, August 4-9, 1991, Boston, MA.

[3] R. Button and A. Brush, "Stability Testing and Analysis of a PMAD DC Test Bed for the Space Station Freedom", IECEC-92, August 3-7,1992, San Diego, CA.

[4] R. Lebron, R. Bodi, and A. Ollver "Test and Evaluation of Load Converter Topologies Used in the Space Station Freedom Power Management and Distribution DC Test Bed.", IECEC-91, August 4-9,1991, Boston, MA.

[5] D. Decker and L.Inouye, "Multikilowatt Power Electronics Developments for Spacecraft", IECEC-91, August 4-9,1991, Boston, MA.

[6] R. Thornton and D. Fox, "Power Management and Distribution Equipment Development for Space Applications", IECEC-91, August 4-9,1991, Boston, MA.

[7] D.K. Decker and L.Y. Inouye, "Operation of High Power Converters in Parallel", IECEC-92, August 3-7,1992, San Diego, CA. 


\begin{tabular}{|c|c|c|c|c|}
\hline \multicolumn{3}{|c|}{ REPORT DOCUMENTATION PAGE } & & $\begin{array}{l}\text { Form Approved } \\
\text { OMB No. 0704-0188 }\end{array}$ \\
\hline \multicolumn{5}{|c|}{ 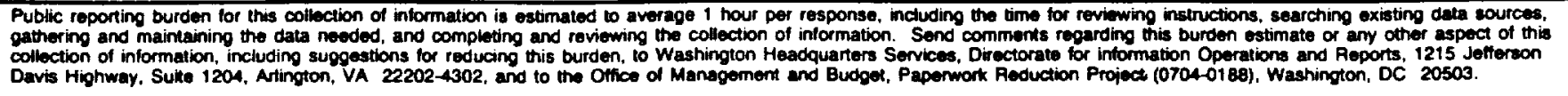 } \\
\hline 1. AGENCY USE ONLY (Loave Dlank) & $\begin{array}{r}\text { 2. REPOAT DATE } \\
\text { August } 1992\end{array}$ & \multicolumn{3}{|c|}{$\begin{array}{l}\text { 3. REPOAT TYPE AND DATES COVERED } \\
\text { Technical Memorandum }\end{array}$} \\
\hline \multicolumn{3}{|c|}{$\begin{array}{l}\text { 4. TILE AND SUBTILE } \\
\text { Load Converter Interactions With the Secondary System in the Spac } \\
\text { Station Freedom Power Management and Distribution DC Test Bed }\end{array}$} & \multicolumn{2}{|c|}{ 5. FUNDING NUMBERS } \\
\hline \multicolumn{3}{|l|}{ 6. AUTHOA(S) } & \multicolumn{2}{|c|}{ WU-474-42-10 } \\
\hline \multicolumn{3}{|c|}{$\begin{array}{l}\text { National Aeronautics and Space Administration } \\
\text { Lewis Research Center } \\
\text { Cleveland, Ohio } 44135-3191\end{array}$} & \multicolumn{2}{|c|}{$E-7287$} \\
\hline $\begin{array}{l}\text { 9. SPONSORINGMONITORING AC } \\
\text { National Aeronautics and } \\
\text { Washington, D.C. } 20546\end{array}$ & $\begin{array}{l}\text { ENCY NAMES(S) AND ADDRESS(ES } \\
\text { Space Administration } \\
0001\end{array}$ & & \multicolumn{2}{|c|}{ NASA TM-105844 } \\
\hline \multicolumn{5}{|c|}{$\begin{array}{l}\text { 11. SUPPLEMENTAAY NOTES } \\
\text { Prepared for the 27th Intersociety Energy Conversion Engineering Conference cosponsored by the ANS, SAE, } \\
\text { ACS, AIAA, ASME, and IEEE, San Diego, California, August 3-7, 1992. Ramon C. Lebron, NASA Lewis } \\
\text { Research Center, Cleveland, Ohio. Responsible person, Ramon C. Lebron, (216) 433-8325. }\end{array}$} \\
\hline $\begin{array}{l}\text { 12a. DiSTAIBUTION/AVAILABILTT } \\
\text { Unclassified - Unlimited } \\
\text { Subject Category } 33\end{array}$ & STATEMENT & & \multicolumn{2}{|c|}{ 12b. DISTAIBUTION CODE } \\
\hline \multicolumn{5}{|c|}{$\begin{array}{l}\text { 13. ABSTAACT (Max/mum } 200 \text { words) } \\
\text { The NASA Lewis Research Center in Cleveland, Ohio, is responsible for the design, development, and assembly of the } \\
\text { Space Station Freedom (SSF) Electrical Power System (EPS). In order to identify and understand system level issues } \\
\text { during the SSF Program design and development phases, a system Power Management and Distribution (PMAD) DC test } \\
\text { bed was assembled. Some of the objectives of this test bed facility are the evaluation of, system efficiency, power quality, } \\
\text { system stability, and system protection and reconfiguration schemes. In order to provide a realistic operating scenario, dc } \\
\text { Load Converter Units are used in the PMAD dc test bed to characterize the user interface with the power system. These } \\
\text { units are dc to dc converters that provide the final system regulation before power is delivered to the load. This final } \\
\text { regulation is required on the actual space station because the majority of user loads will require voltage levels different } \\
\text { from the secondary bus voltage. This paper describes the testing of load converters in an end to end system environment } \\
\text { (from solar array to loads) where their interactions and compatibility with other system components are considered. Some } \\
\text { of the system effects of interest that are presented include load converters transient behavior interactions with protective } \\
\text { current limiting switchgear, load converters ripple effects, and the effects of load converter constant power behavior with } \\
\text { protective features such as foldback. }\end{array}$} \\
\hline \multirow{2}{*}{\multicolumn{4}{|c|}{$\begin{array}{l}\text { 14. SUBJECT TERMS } \\
\text { Space station power supplies; Voltage converters (DC to DC); Power converters }\end{array}$}} & \begin{tabular}{|c|} 
15. NUMBER OF PAGES \\
8 \\
\end{tabular} \\
\hline & & & & $\begin{array}{r}\text { 16. PAICE CODE } \\
\text { A02 }\end{array}$ \\
\hline $\begin{array}{l}\text { 17. SECUATTY CLASSIFICATION } \\
\text { OF REPOAT } \\
\text { Unclassified }\end{array}$ & $\begin{array}{l}\text { 18. SECUATY CLASSIFICATION } \\
\text { OF THIS PAGE } \\
\text { Unclassified }\end{array}$ & $\begin{array}{l}\text { 19. SEC } \\
\text { Of }\end{array}$ & ATION & 20. UMMTATION OF ABSTRACT \\
\hline
\end{tabular}

